\begin{tabular}{c|c|c}
\hline \hline & MARINE ECOLOGY PROGRESS SERIES \\
Vol. 215: 303-305, 2001 & Mar Ecol Prog Ser & Published May 31 \\
\hline \hline
\end{tabular}

\title{
COMMENT
}

\section{Evaluating the 'reliability' of filtration rate measurements in bivalves}

\author{
Peter J. Cranford* \\ Fisheries and Oceans Canada, Marine Environmental Sciences Division, Bedford Institute of Oceanography, PO Box 1006, Dartmouth, \\ Nova Scotia B2Y 4A2, Canada
}

The study of the physiology of bivalve suspension feeding has resulted in an extensive and diverse literature, but remains controversial as a result of divergent interpretations of the large body of data (Jørgensen 1990, 1996, Hawkins \& Bayne 1992, Bayne 1993, Bayne 1998). This controversy has recently been heightened by Riisgård (2001) in a review of published filtration rate measurements in which he attempts to identify 'reliable' data within what he describes as 'heaps of conflicting data'. Whether or not these data are actually conflicting is central to the controversy. The wide range of filtration and clearance rate measurements reported in the literature are clearly in conflict with the view that bivalve feeding is a highly automated and unregulated process that greatly limits the range of potential filtration rate responses (Riisgård \& Larsen 1995, Clausen \& Riisgård 1996, Jørgensen 1996). However, others interpret the large variance in experimental and observed responses as evidence of direct physiological control linked to variability in the food supply (e.g. Hawkins \& Bayne 1992, Bayne 1993, 1998). It is important for new readers of this literature to keep this underlying context in mind when following Riisgård's (Riisgård 2001) search for 'reliable' data.

Riisgård (2001) scrutinized the literature with the intent 'to point out some reliable (i.e. no methodological flaws) filtration rate data obtained under optimal laboratory conditions' in an attempt to dismiss what he calls 'erroneous interpretations'. A similar critical examination was undertaken by Jørgensen (1996). Although a large body of work has been called into question, I will confine my comments to Riisgård's criticisms of the reliability of my own data. For an insightful discussion on the merit of Jørgensen's critique, I refer readers to Bayne (1998). My reluctant foray into this debate extends primarily from the development of the in situ biodeposition approach for autonomously

\footnotetext{
*E-mail: cranfordp@mar.dfo-mpo.gc.ca
}

and continuously measuring feeding and digestion processes in bivalves (Cranford \& Hargrave 1994). This methodology was subsequently utilized to study short(Cranford et al. 1998) and long-term (Cranford \& Hill 1999) variations in bivalve feeding behaviour. The availability of in situ measurements on undisturbed bivalves exposed to natural dietary conditions was viewed as an opportunity to test clearance rate predictions based on a wide variety of available in vivo clearance rate models, including the widely applied models of Riisgård \& Möhlenberg (1979) and Möhlenberg \& Riisgård (1979). The observation of relevance here is that clearance rate predictions based on laboratory measurements using only algal cell diets (i.e. optimal laboratory conditions) were, on average, 320 to $1365 \%$ higher than the in situ measurements (Cranford \& Hill 1999). This result confirmed similar observations reported in numerous cited studies, which collectively indicate that while bivalves in nature do fully exploit their clearance capacity for short periods (Cranford et al. 1998), they more often feed at a much reduced rate (Cranford \& Hill 1999).

As for all experiments with living organisms, filtration and clearance rate measurements require close attention to the potential negative effects of experimental conditions (Jørgensen 1996). It was with these concerns in mind that the in situ biodeposition approach was applied. Riisgård (2001) suggests that the biodeposition method produces errors induced by pseudofaeces production and methods of diet characterization. These potential sources of error have been thoroughly and quantitatively addressed elsewhere (Cranford \& Hargrave 1994, Cranford et al. 1998, Cranford \& Hill 1999) and cannot explain the often large difference in clearance rates measured in situ and observed under optimal laboratory conditions. An important component of our work has been to carefully and objectively assess the assumptions of the method (Cranford et al. 1998) as well as determining if the estimates are 'reliable' (Cranford \& Hill 1999). Precision 
and accuracy, defined as how much measurements deviate from the central and true values, respectively, are the primary criteria by which the 'reliability' of any data must be based. Riisgård (2001) has chosen not to present published data on the high precision and accuracy of our clearance rate estimates (Cranford \& Hill 1999). We used the approach outlined in Clausen \& Riisgård (1996) to assess measurement accuracy and showed that tissue growth predictions based on our clearance rate estimates were comparable with the observed growth of the animals used in the feeding experiments (Cranford \& Hill 1999).

If data reliability is not based on an analysis of data precision and accuracy, how can it be judged objectively? The approach of Riisgård (2001) is to judge reliable data by searching for potential methodological pitfalls and flaws and by determining if the methods meet 'the necessary prerequisites'. In general, his examination and description of available methods is clear and insightful and will aid new researchers in selecting and properly applying many laboratory techniques for feeding experiments. However, his prerequisite that reliable filtration rate data must come from methodologies that provide results comparable to those measured for fully open bivalves under 'optimal laboratory conditions' (see Table 1 in Riisgård 2001) lacks scientific objectivity and is designed to exclude equally valid reasons for data variability. This prerequisite was used as the primary basis for questioning the reliability of any published filtration rates that were lower than he predicted, including many data provided by the biodeposition method. A suggested explanation for the observed low filtration rates was that 'sub-optimal conditions may be prevailing'. Considering that the definition of optimal conditions includes a carefully controlled laboratory diet consisting of an algal cell monoculture, optimal conditions can never prevail in nature. The prerequisite that measurements be performed on fully open bivalves is also questionable as in situ video observations show large natural temporal variations in shell gape (e.g. Newell et al. 1998), a measure that is correlated with filtration rate (Jørgensen et al. 1988).

After suggesting that the biodeposition method may be invalid, Riisgård used the relatively high clearance rates reported for sea scallops Placopecten magellanicus by Cranford et al. (1998) to question the reliability of lower values reported by MacDonald \& Thompson (1986). While Riisgård is correct to point out that the geometry of flow-through chambers, such as used in the latter study, can provide erroneously low results, the potential for mixing within the chamber is easily tested and is routinely checked at each flow rate employed. A low clearance rate is not a valid reason in itself for concluding that a methodological problem exists. For example, Riisgård implies that the relatively high clearance rates measured using flow-through chambers by Cranford \& Gordon (1992) is evidence of a recirculation problem in the MacDonald \& Thompson (1986) study. What he failed to mention was that Cranford \& Gordon (1992) showed that these high rates immediately decreased by a factor of 3 when the algal cell diet was replaced with a natural seston diet. As the flow conditions in the chamber were identical for both diets, the latter result cannot be explained by potential methodological problems, but strongly supports the results of MacDonald \& Thompson (1986), which were also based on a seston diet. Selective literature reviews and inconsistent interpretations of the validity of methodologies and results must always be viewed with caution.

Bivalve growth has been extensively studied but the relationship with environmental conditions is often poorly understood (Grant 1996). An understanding of the potential interplay between the physiological processes that limit food utilization and all potential exogenous and endogenous forcing functions is fundamental to the prediction of bivalve growth. Ample filtration rate data can be found in the literature that appear incompatible with any of the present theories of bivalve suspension feeding behaviour. The way to move forward is not to evaluate data reliability based on anticipated responses, but to focus attention on establishing standard and objective means of quantitatively addressing data accuracy under environmentally relevant experimental conditions. Research efforts to provide filtration rate measurements in the field have increased considerably in the last few years and we need to continue to encourage this effort rather than promoting the use of optimal laboratory conditions that constrain the potential for further insight.

\section{LITERATURE CITED}

Bayne BL (1993) Feeding physiology of bivalves: time-dependence and compensation for changes in food availability. In: Dame RF (ed) Bivalve filter feeders in estuarine and coastal ecosystem processes., NATO ASI Series, Vol G 33, Springer-Verlag, Heidelberg, p 1-24

Bayne BL (1998) The physiology of suspension feeding bivalve molluscs: an introduction to the Plymouth 'TROPHEE' workshop. J Exp Mar Biol Ecol 219:1-19

Clausen I, Riisgård HU (1996) Growth, filtration and respiration in the blue mussel, Mytilus edulis: no evidence for physiological regulation of the filter-pump. Mar Ecol Prog Ser 141:34-45

Cranford PJ, Gordon DC Jr (1992) The influence of dilute clay suspensions on sea scallop (Placopecten magellanicus) feeding activity and tissue growth. Neth J Sea Res 30: 107-120

Cranford PJ, Hargrave BT (1994) In situ time-series measurement of ingestion and absorption rates of suspension-feed- 
ing bivalves: Placopecten magellanicus. Limnol Oceanogr 39:730-738

Cranford PJ, Hill PS (1999) Seasonal variation in food utilization by the suspension-feeding bivalve molluscs Mytilus edulis and Placopecten magellanicus. Mar Ecol Prog Ser 190:223-239

Cranford PJ, Emerson CW, Hargrave BT, Milligan TG (1998) In situ feeding and absorption responses of sea scallops Placopecten magellanicus (Gmelin) to storm-induced changes in the quantity and composition of the seston. J Exp Mar Biol Ecol 219:45-70

Grant J (1996) The relationship between bioenergetics and the environment to the field growth of cultured bivalves. J Exp Mar Biol Ecol 200:239-256

Hawkins AJS, Bayne BL (1992) Physiological interrelations, and the regulation of production. In: Gosling $\mathrm{E}$ (ed) The mussel Mytilus: ecology, physiology, genetics and culture. Elsevier, Amsterdam, p 171-222

Jørgenson CB (1990) Bivalve filter feeding: hydrodynamics, bioenergetics, physiology, and ecology. Olsen and Olsen, Fredensborg

Jørgenson CB (1996) Bivalve filter feeding revisited. Mar Ecol Prog Ser 142:287-302

Jørgenson CB, Larsen PS, Møhlenberg F, Riisgård HU (1988)
The mussel pump: properties and modelling. Mar Ecol Prog Ser 45:205-216

MacDonald BA, Thompson RJ (1986) Influence of temperature and food availability in the ecological energetics of the giant scallop Placopecten magellanicus III. Physiological ecology, the gametogenic cycle and scope for growth. Mar Biol 93: 37-48

Møhlenberg F, Riisgård HU (1979) Filtration rate, using a new indirect technique, in thirteen species of suspension-feeding bivalves. Mar Biol 54:143-147

Newell CR, Campbell SM, Gallagher SM (1998) Development of the mussel aquaculture lease site model MUSMOD ${ }^{\odot}:$ a field program to calibrate model formulations. J Exp Mar Biol Ecol 219:143-169

Riigård HU (2001) On measurement of filtration rates in bivalves - the stony road to reliable data: review and interpretation. Mar Ecol Prog Ser 211:275-291

Riigård HU, Larsen PS (1995) Filter-feeding in marine macroinvertebrates: pump characteristics, modelling and energy cost. Biol Rev 70:67-106

Riisgård HU, Møhlenberg F (1979) An improved automatic recording apparatus for determining the filtration rate of Mytilus edulis as a function of size and algal concentration. Mar Biol 52:61-67 